\title{
Is quantitative easing good policy?
}

\author{
Stephen Anthony ${ }^{1}$
}

\section{Abstract}

This paper asks whether the suite of unorthodox monetary policies (including quantitative easing, or $\mathrm{QE}$ ) really make sense in the presence of a global liquidity trap. It finds that QE-type policies are an expedient remedy for short-term crisis management, but their ongoing and expanded use have distorted global markets and will have significant dynamic efficiency costs over the next decade. The alternative is for discretionary fiscal policy to play a bigger role in stabilisation, with monetary policy left to accommodate. Both policies should be operated by a single agency accountable to the electorate.

From the Monetarist view that I am taking, of course, nothing could be more conventional than 'quantitative easing'.

— Robert E. Lucas, Jr (2014, p. 208)

In fact, it appears that there can be no stable dynamic model of the economy that allows government to use fiscal and monetary policy independently.

— Fisher Black (1987, p. 28)

In my first week at the Commonwealth Treasury in 2000, I attended a monetary policy seminar at which then secretary, the late Ted Evans, asked a simple question: 'What is money?' ${ }^{2}$ This was his strongpoint: making a profound point by asking basic, soft-spoken questions. It stumped everyone in the room. In what may have been prophetic insight, that question is still at the heart of our economic travails today. This is as most advanced Organisation for Economic Co-operation and

\footnotetext{
1 University of Canberra and Macroeconomics Advisory; stephen.anthony@macroeconomics.com.au.

2 The question is discussed throughout this piece. The answer underpins how you think about monetary policy or the set of strategies intended to stabilise the value of money, prices and output. Financial stability objectives are assumed to be the focus of (macro) prudential regulation (Trott, 2015).
} 
Development (OECD) economies have progressively sunk into a global liquidity trap since the Global Financial Crisis (GFC), with zero or even negative ratessome out beyond 10 years.

The new world of very low rates has seen changes in the operation of stabilisation policy across economies since the GFC. For the first time since the Great Depression, it has been essential in many economies for monetary authorities to implement policy via 'quantity' and not 'price'. ${ }^{3}$ Meanwhile, consumer price inflation has remained persistently below target levels.

Many prominent economists overseas (see Summers, 2013) and in Australia (see Garnaut, 2021, p. 133) argue that the ultra low interest rates and trend growth are mainly due to a fall in real interest rates because of underlying savings: investment determinants, driven by deteriorating demographics, technological change and poor policy choices. Their economic argument is that the increase in savings caused mainly by the ageing population led to a fall in the natural rate of interest as the supply of loanable funds rose relative to demand. So, the 'neutral' rate of interest fell as the supply of loanable funds increased relative to demand. ${ }^{4}$

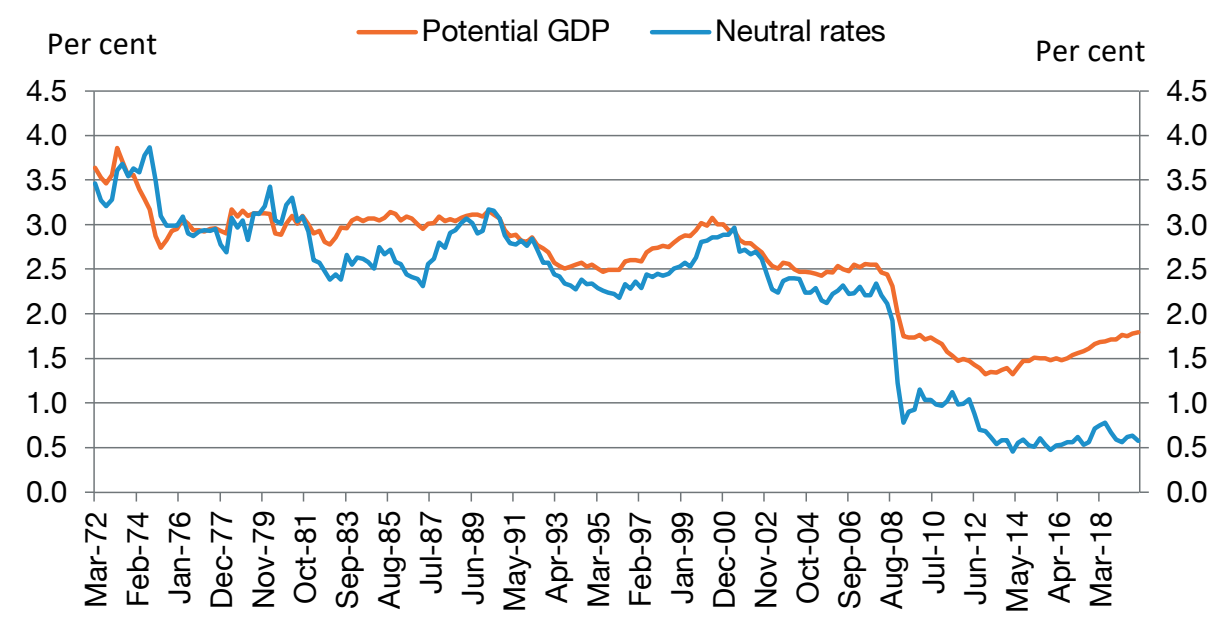

Figure 1. Neutral interest rates and potential GDP growth (select advanced economies)

Note: Select advanced economies include the United States, members of the euro area, the United Kingdom and Canada. A broadly similar pattern was observed for Australia.

Sources: Holston et al. (2017); and Jones (2021).

\footnotetext{
3 This assumes that negative rates are untenable for the health of the banking system.

4 The neutral rate is the estimated rate of interest that supports full employment while inflation and growth are steady.
} 
The 'secular stagnation' story is certainly a contributing factor, but not the main driver of what has occurred over the past decade. ${ }^{5}$ More relevant has been the choice of monetary regime defined by the central banks' policy-setting (reaction function) (Borio et al., 2017). In our view, the sudden drop-off and stubbornly low levels of neutral interest rates in countries like Australia since the onset of the GFC are difficult to reconcile with slow-moving patterns of productivity or demographics. Also curious is the lack of a reflexive business investment rebound given strong corporate profitability (Figure 1).

Nor does secular stagnation properly account for the major reversal in the polarity of finance in advanced economies since the mid-1990s (Howell, 2020). In this reversal, large corporations generate more cash from existing operations (through cost-cutting and perhaps economic rents) and hold these funds in financial markets (not banks) (Montier, 2018). Hence, banks now borrow (indirectly via wholesale markets) from corporations and lend to households via mortgages. In this new era, the refinancing of existing positions (gross investment) is more important than new CapEx (net investment).

So, balance sheet capacity (that is, liquidity or quantity) matters far more than interest rates (price). Consequently, central banks' attempts to 'control' wholesale markets have seen them, little by little, resort to maintaining larger balance sheets based on the desire to spur more risk-taking by lenders, concurrently increasing their balance sheet size (Montier, 2018).

The key problem with policy today is, therefore, that for 20 years or more the biggest user of money has been the financial sector itself and not the real economy. This fact has scarcely dawned on most of us (Tinkler, 2020). While economics may or may not adequately address issues with the real economy, these accounted for less than 20 per cent of flows in the international payment system in 2021 (Lucas, 2014 , p. 209). This leaves a massive unaccounted residual of what we might call dark matter, which is driven by transaction flows related to asset purchases, portfolio diversification and speculation. The big gap explains why economic theory provides little guidance in the face of financial market volatility.

\section{QE basics}

The contemporary form of quantitative policy operation was introduced to most of us courtesy of the US Federal Reserve's quantitative easing (QE) program from 2009 (Figure 2). QE, in its latest iteration, involves the purchase of 'safe assets' (usually

5 This assumes lending is carried out by banks to non-financial firms and that independent central banks influence such credit flows via adjustments to an equilibrium or neutral rate (Ryan-Collins, 2015), whereas, since the GFC, banks want to make residential real estate loans to investors, not SME business loans. The reasons are macro-prudential. 
public debt) from private financial institutions (banks and primary dealers) with the objective of directly injecting more cash into money markets, ideally to spur aggressive lending by financial institutions. This occurs during periods in which they may be loath to lend. ${ }^{6}$

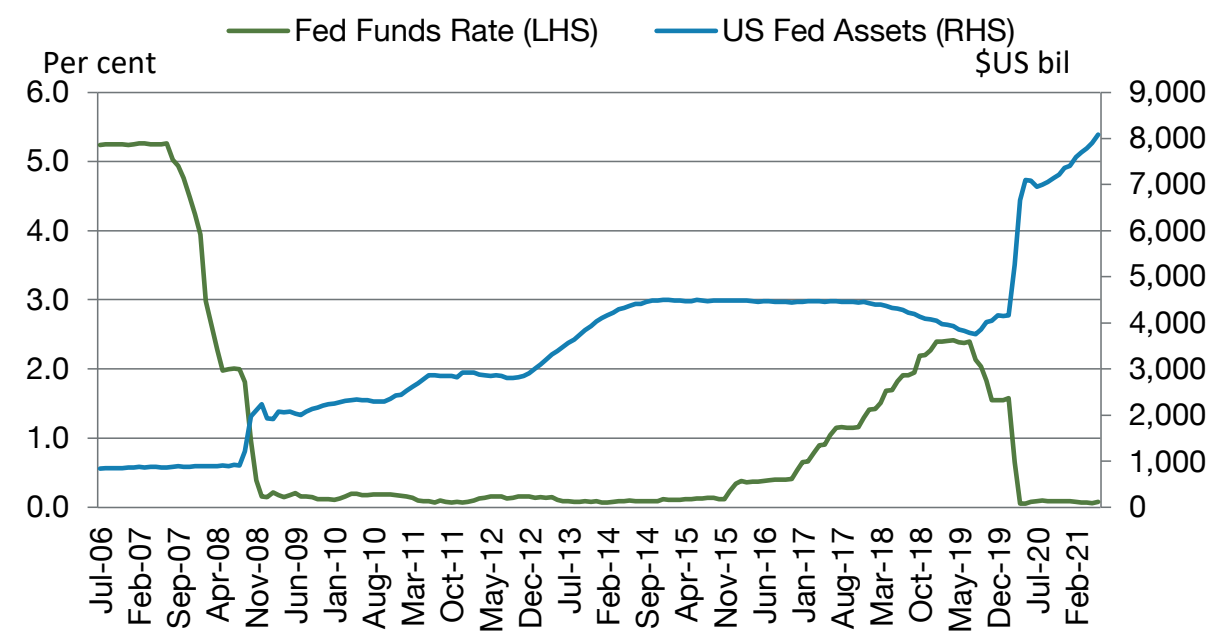

Figure 2. The Federal Reserve balance sheet and funds rate since the mid-2000s Source: FRB; Haver.

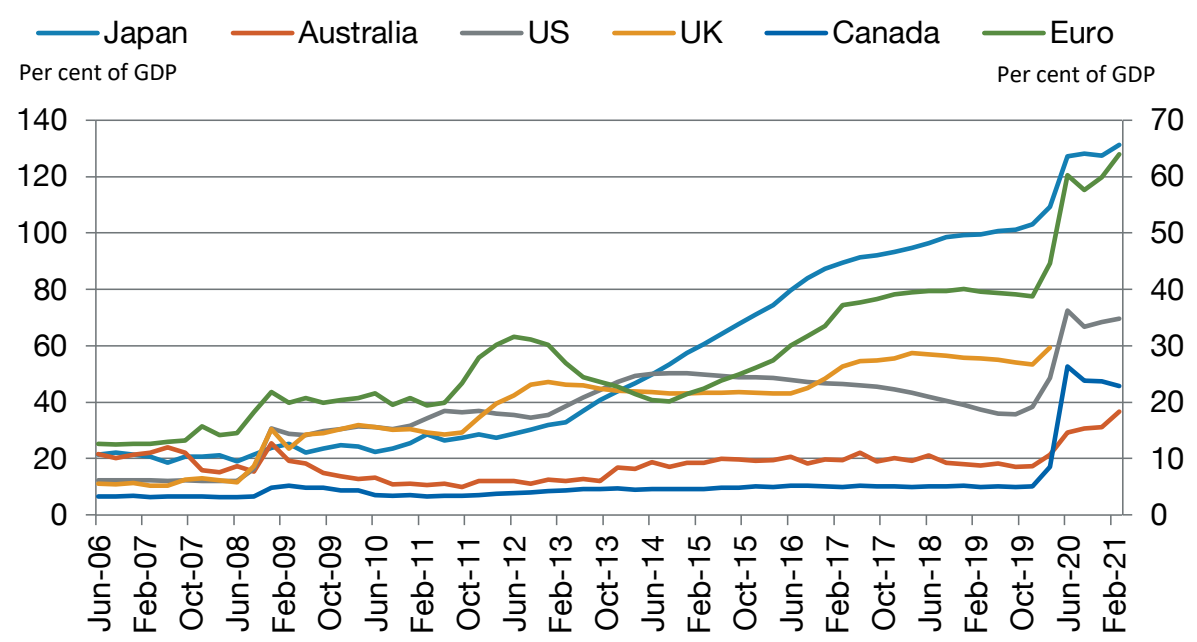

Figure 3. Selected central bank balance asset shares since the mid-2000s

Sources: BoJ; RBA; FRB; BoE; BoC; ECB; Haver.

6 QE is a policy mechanism to achieve macroeconomic stabilisation policy via quantity (that is, asset purchases) rather than passive signalling through price settings (official rates/yield curve). 
Throughout the 2010s, each so-called advanced economy permitted its central bank to roll out its own domestic QE programs as one after another was buffeted by a wave of common global financial macro-shocks (the GFC, European sovereign debt crisis, taper tantrum, repo crisis, Covid-19 pandemic and so on). One of the last nations to join the club, in September 2020, was Australia (Figure 3).

The balance sheets of major central banks (excluding China’s) grew from US $\$ 4$ trillion before the GFC to US $\$ 16$ trillion by 2018 , before surging to US $\$ 26$ trillion in the latest reading, in June 2021.

In the United States, in mid-2021, the Fed was still buying US\$120 billion of Treasury bonds (holding 25 per cent of the available stock) and US\$40 billion of securitised mortgages each month, even with housing in short supply.

The fundamental policy goals are to facilitate transactions and maintain liquidity in money and credit markets. This then allows otherwise profitable business entities to operate. But elaborating a little further, the list is quite long:

- Rescuing economies in the economic 'emergency room'.

- Financing government spending at low, zero or negative real interest rates, adjusting for inflation.

- Restoring consumer inflation and output.

- Ensuring the vitality of credit lending channels by propping up the collateral of the financial sector.

The success or otherwise of trillions of dollars of stimulus is dependent on the effectiveness of the transmission mechanisms through which $\mathrm{QE}$ is supposed to work. Our view is that there are four identifiable mechanisms in play with QE, but only three (not 'duration') are likely to contribute to raising activity. Each of these channels is listed below.

1. Portfolio risk channel: Expanding public liquidity increases term premiums on government bonds while lowering the term premiums assigned to risk assets:

- The 'official' line is that $\mathrm{QE}$ drives up the demand for bonds and drives down the yield on assets. Perhaps surprisingly, this effect is not sustained in the data; in fact, quite the reverse.

- The sustained impact of QE seems to occur as private institutions tilt towards risk assets and away from safe government securities. They do this safe in the knowledge that authorities have their back (Howell, 2020). So, portfolio rebalancing (slack demand) raises the risk premiums on safe assets. There is a corresponding lowering of the risk premiums of risky assets as private agents chase capital gains. 
- The impact is then magnified by the asset price accelerator (that is, collateral effects) whereby increases in housing prices improve balance sheets and stimulate further mortgage lending.

2. Duration channel: The expansion of central bank money leads to tighter supplies of higher-yield and long-duration assets, which might tend to lower yield over time. $^{7}$

3. Financing channel: More public liquidity eases funding conditions for credit providers via repos and so on, which thaw frozen markets and aid circulation of capital. ${ }^{8}$

4. Exchange rate channel: More public liquidity weakens the currency unit and so raises the competitiveness of traded goods - although these effects will be diluted by cross-country policy movements, especially those of large economies.

Another dimension of QE is to think about the central bankers' policy function. Here, good policy engenders new private spending without significant changes in the central bank balance sheet (Trott, 2015). However, where this trade-off is more costly or even illusory, a central bank could accumulate massive assets without achieving anything other than imposing efficiency costs on current and future generations.

\section{Intermediation}

With the trillions of dollars being spent on QE stimulus over the past decade, is credit smoothly and efficiently passing from central banks to small business and householders, where it is needed to drive stronger economies?

Traditionally, central banks employed their diverse network of savings and loantype banking institutions to push loans directly to local communities. This type of decentralised banking was built on trust and provided a stable basis for monetary control of an economy through captive deposits. ${ }^{9}$ The reality now is there is no community-based branch-banking linkage in modern banking and, if there was anything left in the late 2000s, the GFC and subsequent Basel reforms killed it off.

\footnotetext{
7 But if private agents simultaneously demand fewer safe assets, the impact only dampens and does not nullify the risk channel, whereas policymakers might argue that they deliberately create a scarcity of duration by buying long-dated bonds - that is, a subset of the portfolio channel.

8 Repos (repurchase agreements) are a form of short-term borrowing for dealers in government securities. In the case of a repo, a dealer sells government securities to investors - usually on an overnight basis—and buys them back the following day at a slightly higher price. When market liquidity is tight, dealers charge extreme margins and market freeze quickly.

9 Think of George Bailey, the protagonist in Frank Capra's 1946 film, It's a Wonderful Life. He inadvertently inherits his father's management of a failing building and loans bank in the community of Bedford Falls, sacrificing his dreams along the way.
} 
Now our banking systems have become far more impersonal and far more reliant on securitised residential housing loans. Unfortunately, due to the changing polarity of finance from the mid-1990s, banks now rely on wholesale funding markets rather than local branch deposits to secure their funding base. To access wholesale funding markets, banks, too, must offer up collateral underpinned by the loans they write each month. The search for collateral inevitably leads them to residential housing markets and securitised lending. Unfortunately, this collateral base is very procyclical and so further magnifies the QE liquidity cycle, making the housing market prone to more boom-and-bust gyrations.

Now our banking systems are also less competitive and more reliant on systemically important players in each jurisdiction to ensure stability and carry our policy objectives. Since the GFC and successive Basel reforms, if not before, central banks have placed a few privileged private financial institutions in the driver's seat to control financial intermediation via a top-down process. Needless to say, the privileged few can then ration credit to whomever they please, thus undermining competition and locking out a plethora of market-making and prime brokers in the middle of intermediation chains.

Take the United States' case.

If the Federal Reserve injects liquidity into the marketplace, it locates funds on the balance sheets of key banks, investment funds and broker dealers. The Wall Street names include the 15 big private US banks (including JP Morgan Chase, Bank of America, Citigroup and Wells Fargo) and big investment funds such as Blackrock. These institutions are then instructed to loan funds to smaller financial intermediaries and non-financial corporations. Is this what they do? Not directly. There are at least two steps.

Step 1: The gatekeeper institutions — with access to the Fed's borrowing windowfirst use their preferred position to buy risk-free bonds (Treasury bonds), which they then use as collateral to conduct repos. This generates cash for them to buy junk bonds (BBB, CCC and lower) and other financial products (structured products, derivatives, swaps, private equity assets, tech shares and so on). ${ }^{10}$ So, they use their preferred positions as primary participants to generate speculative profits. For evidence, think back to the rapid recoveries made by each of these businesses after the Lehman Brothers collapse.

Step 2: The gatekeeper institutions then use their market dominance to gouge out the eyes of competitors (numerous second and third-tier players). Meanwhile, they extract rents from their customer base while undertaking their policy mandate to

10 This helps to explain the hypersensitivity of repos to liquidity conditions in cash and credit markets. 
write new business loans. This is why the Federal Reserve was creating new programs to provide credit to small and medium-sized enterprises (SMEs) during the worst days of the Covid-19 downturn in 2020.

Each advanced economy has its own version of this strategic participants' game with credit rationing.

\section{Quantity theory justification}

We have considered what QE-type policies aim to achieve and how they might be transmitted and intermediated at the microlevel. Now we think about how QE-type policies work in aggregate at the macroeconomic level in terms of the conduct of stabilisation policy. To conduct policy by quantity means it is apt that we reference one of the oldest identities in economics: the quantity theory of money (MV = PQ).

\section{Theories}

The quantity model says that money is effectively a scalar assuming the $\mathrm{V}$ (velocity of money) and Q (real output) are invariant to the flow of money feeding through to $\mathrm{P}$ (prices). ${ }^{11}$ So, money is a neutral scalar-a homogeneous block of cash-that can be expanded or contracted like an accordion to play the sweet music of an economy playing in tune. ${ }^{12}$ Quantity theory underpinned what there was of macroeconomics before Keynes.

Historically, the quantity theory was quite robust although, by the early 1980s, time series could no longer bear the invariance of V or Q. ${ }^{13}$ Therefore, it seems that adding money does not directly feed through to inflation as QE would require. Instead, as Paul Krugman has noted, excess printing of money simply causes the ratio of GDP to money (its circulation velocity) to fall (Figure 4). ${ }^{14}$

How can we use the quantity theory in thinking about QE? Keynes's $(1936,1937)$ key insight was to ask people to see money not as some giant block of cheese, but as something that is manufactured, first, by central banks and, then, by an infinite number of private intermediaries to eventually 'feed' the liquidity into the economy. To Keynes, velocity was in constant flux, system-specific, time-varying and ever changing with intermediation and regulatory structures.

11 The classical understanding of markets assumes wages are flexible and so markets clear. Thus, the quantity of money has no effect on output but merely determines the price level, which is proportional to nominal money supply.

12 Milton Friedman's 1956 restatement of the quantity depends on a stable demand for money balances or a predictable ratio of saving to spending to hand central banks control over prices.

13 Something changed with the floating of the US dollar and global deregulation of financial markets from the early 1970 s onwards.

14 The velocity of money was falling in countries like the United States and Australia during the entire 2010s, if not earlier, from about 1.5 to about 0.8 across economies (Figure 4). When central banks pump out the money, more of it just sits on bank balance sheets. 


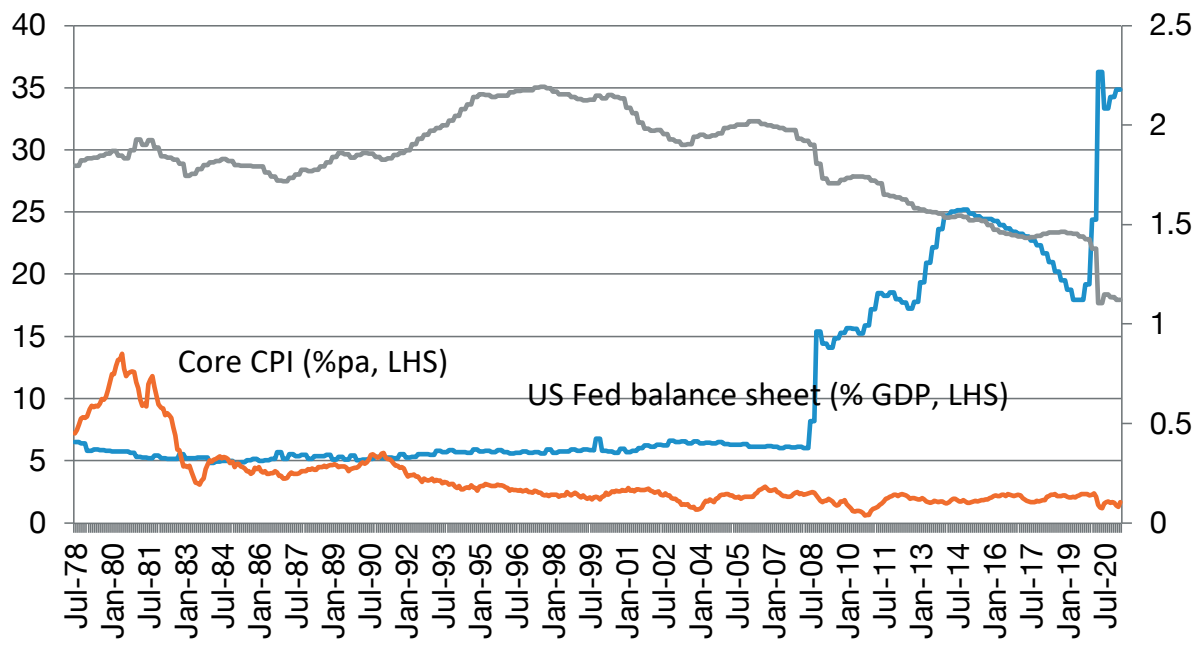

Figure 4. US QE, money supply and consumer price index

Sources: BLS for CPI; BEA for GDP; FRB; Haver for QE and money.

\section{Keynes's insights}

Keynes challenged economists to think of money as a complex vector of extending components, M0, M1, M2, .., M17, and so on, and a myriad substitutable credit forms with tight bid-ask spreads (Samuelson \& Barnett, 2007). Money is not a scalar or singularity. Money is a set of substitutable assets. The closeness of their interweave depends on the structure of intermediation chains and the abundance of supplies of high-grade, low-interest-bearing paper. In the right set of circumstances, it would be possible to leverage supplies of central bank-initiated assets. So, money creation can turn into a torrent or procyclical wave through the private sector-noting that all broader money and credit forms always lead the business cycle. Ironically, the notion of the heterogeneity of money would not be news to strict monetarists either (Brunner, 1983, p. 184). ${ }^{15}$

\section{Liquidity preference}

Keynes used the term 'liquidity preference' to describe the idea that investors would not part with their portfolio cash unless they perceived that the relative riskadjusted returns from an investment would be adequate. ${ }^{16}$ Keynes maintained that

15 Keynesians emphasise the substitution effects of money as an alternative to other financial assets, while monetarists highlight the income or wealth effects (Morgan, 1978, p. 77).

16 In Chapters 22 and 25 of the General Theory, Keynes explains why he criticised the older economists for arguing that interest rates would equate to the flow of saving to investment. What Keynes termed the speculative demand for money was identified by Hawtrey (1925), who argued that when trade is slack, businesses accumulate cash balances. 
portfolio managers do not have to put their wealth out to invest. In the face of market conditions like those of the 1930s and 2010s, they could just delay capital formation. Here, portfolio managers and investment committees hide the money 'under their bed', buy gold or real estate, or just send the money back to shareholders. In other words, they may park their money somewhere or chase safer prospective capital gains. ${ }^{17}$

Keynes argued that it did not make sense to encourage business owners to skimp on dinner and/or close a factory, thus impacting prices; but it did make sense to encourage them to liquidate their portfolio of claims to future money (bonds, stocks) or to borrow from lenders or the central bank if needed to ride out the tough times. ${ }^{18}$

\section{Stabilisation}

Keynes's thinking in the context of the Great Depression and a global liquidity trap was a pro-normalisation strategy. The aim was to encourage private business to borrow and spend. This was supposed drive up the supply of financial assets (credit), increase the pressure on yields to rise and gradually restore activity. He retained a break-glass option, too. If the private economy did fail to relaunch, there was always the option of massive public infrastructure spending, provided it also drove longerterm benefits.

\section{QE justification}

The timeless general theory message is that things often work in reverse order to what you expect. So, real incomes and/or the level of hours worked and/or the level of unemployment are what adjust to clear the money market if interest rates can no longer adjust. To see this simply, suppose: the demand for money depends on output times price $(\mathrm{QP})$ and is proportional, $\mathrm{K}$. So, $\mathrm{Md}=\mathrm{KPQ}$.

- Either prices are fully flexible and $\mathrm{Md}=\mathrm{M}$,

- Or one market is cleared by either $\mathrm{Q}$ or via employment effort (Modigliani, 1944). ${ }^{19}$

17 Keynes's general theory formulation was predicated on the liquidity trap case-for example, operating over a horizontal range of the money demand curve. So, below some positive nominal $\mathrm{r}^{*}$, additional rate cuts have no impact on output. He argued that excess demand for money caused a decline in output and thus the demand for money until demand matched the nominal money supply. With the help of the concept of effective demand, Keynes argued that Say's Law of Markets has been repudiated. The concept of effective demand established that what was produced is not automatically consumed so income would not always be spent at a rate that kept factors fully employed.

18 Note that the RBA employed a number of these type of facilities from April 2020.

19 Unemployment is the variable that clears the money market (with nominal income and interest rates); excess demand for money causes a decline in output and thus the demand for money until the demand matches a given money supply. 
So, the money market can only be cleared via one of two means:

1. reductions in nominal income and employment-QED given rigid prices

2. explicit central bank intervention adding to the supply of money by direct expansion.

This is a longwinded justification for QE based on the quantity theory.

\section{Proportional stimulus}

So, how do you assess the Covid-19 stimulus and broader macro-stabilisation policy in Australia in 2020?

Clearly, it is very hard to judge proportionality in real time; there are ex ante and ex post problems. Armchair experts love to second guess which is okay. But placing yourself back in March and April 2020 when the Covid-19 pandemic hit and governments around the world were placing their economies into 'deep freeze', how would you decide what amount of stimulus was required to tide your economy over? The circumstances were unique and certainly there are no up-to-the-minute contemporaneous economic indicators (the possible exceptions being credit statistics from the Big Four Australian banks and Australian Taxation Office payroll data).

The best policy advice at the disposal of the Australian Government was to try to directly inject into the economy what was being lost by businesses and household ${ }^{20}$ hence, the JobKeeper and JobSeeker approach. Unfortunately, both Treasury and the Reserve Bank of Australia (RBA) put medium-term policy targets to one side. It was as though:

- Keynes was running the Treasury (12 per cent of GDP fiscal stimulus in 12 months to April 2020).

- Modigliani was running the RBA, with a total change in balance sheet of $\$ 300$ billion (15 per cent of GDP monetary stimulus in 12 months to April 2020).

Federal Treasurer Josh Frydenberg oversaw the whole strategy. He signed off on an ad hoc policy target of not reversing policy course until unemployment had fallen to a rate with a ' 4 per cent' in it. ${ }^{21}$ But why not a 5 per cent or even 6 per cent?

Too much stimulus and too fast? Probably. The approach limited the 2020 downturn to a relatively shallow output loss of about 3.5 per cent of GDP in the March and June quarters of 2020 and generated a speedy rebound. That was very good.

20 Listen to the address of Kevin Hassett, former chairman of the President's Council of Economic Advisers, at the 2020 AFR Business Summit in Sydney, 10 March 2020.

21 No doubt, both personally and professionally, this required a deep, personal reset on the part of the Treasurer, knowing that years of future deficits would bear his name. 
At the same time, the fiscal price tag was about $\$ 300$ billion of additional federal debt and the distortionary impacts of RBA QE. Presumably, this means future governments will have less fiscal space to undertake stabilisation. Nor did the federal government's stimulus achieve any permanent structural reform or infrastructure building. This was a big missed opportunity.

Evidence of the generosity of Treasury's fiscal stimulus came with the March Quarter 2021 National Accounts. For the first time in four recession episodes, the Australian non-financial sector and households exited a measured recession with stronger balance sheets then they entered it (Jones, 2021)—at least on average. So perhaps federal macro-stimulus could be accused of being as spendthrift as it surely was in 2008 .

It is worth considering whether both fiscal and monetary stimuli should always be assessed against measured deterioration in employment conditions and unemployment rates. This has been made more straightforward using real-time data collected by the Australian Bureau of Statistics (ABS) and the Australian Taxation Office (ATO). The presumption should be limited to first-round effects and more modest stimulus. Businesses and households that receive stimulus windfalls should be required to repay them.

\section{Does QE raise overall welfare?}

What has been the impact of global QE rounds in the Australian context?

QE helps shore up output and employment in the short term by supporting financial balance sheets and credit flows in times of crisis. But can it support more mediumterm objectives and what does the literature say about this?

\section{What QE is impacting at the macrolevel}

Central bank QE actions do seem to impact private credit provision and output stabilisation in the near term. However, it is not clear whether QE policies have lasting positive impacts in terms of the real economy (Sheedy, 2020). Moreover, one clear takeaway from successive OECD member QE rounds is that programs have two identifiable deleterious impacts.

First, QE rounds lead to 'risk-on' portfolio shifts. Here, money replaces riskier assets (private bonds, stocks, private equity, infrastructure, real estate, bitcoin, art, vintage cars, and so on), leading unambiguously to asset price inflation.

Deutsche Bank (2019) measured asset prices to be at 200-year highs by 2016 across 15 major Western economies, and they have continued to rise since. 
CrossBorder Capital has mapped both the correlation and, more importantly, the causation between QE rounds, global liquidity and financial asset spikes (Figure 5).

Valuations placed on the so-called Nasdaq growth stocks in mid-2021 resemble the Dot.com darlings of the late 1990s, which ended in the Tech Wreck of 2000.

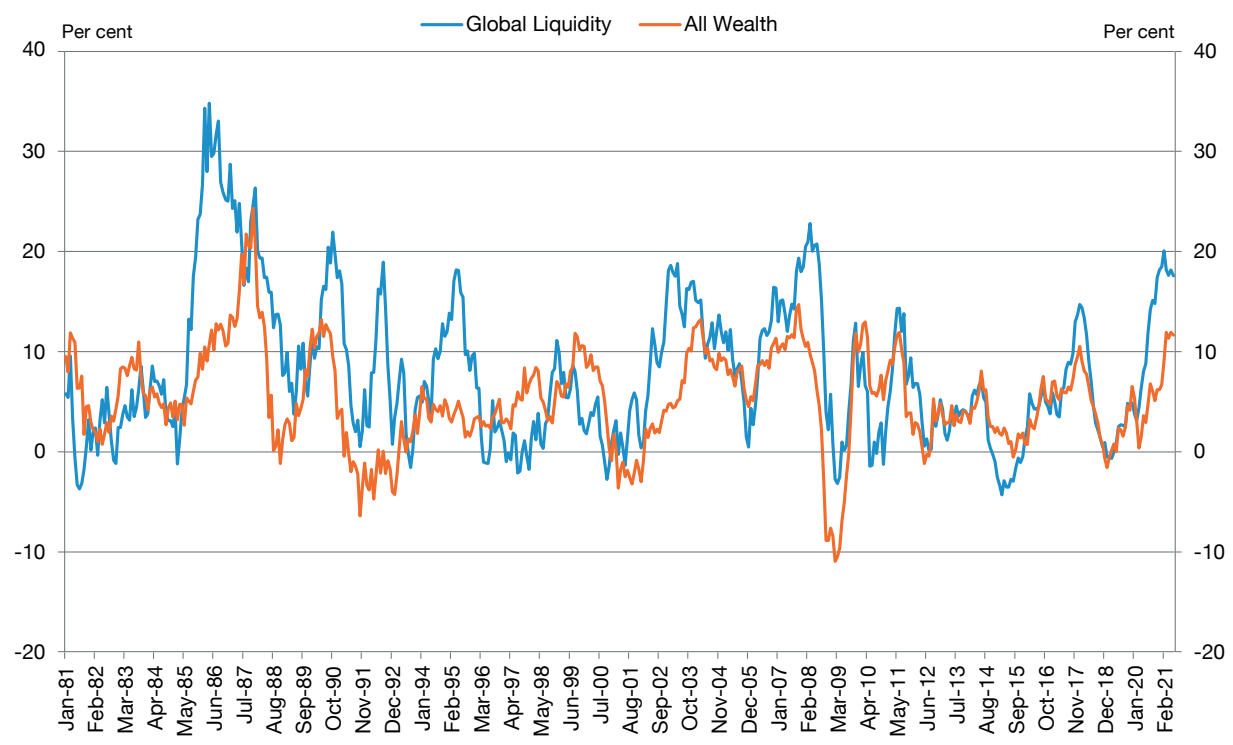

Figure 5. Growth of financial assets and global liquidity

Source: Howell (2020, p. 198, updated by author).

Second, QE rounds have probably helped to choke off private business investment in OECD economies by raising equity hurdle rates and/or the relative riskiness of big capital-intensive construction projects (Figure 6): ${ }^{22}$

- A decade-long business investment drought across OECD member economies coincided with strong profits. Businesses preferred larger dividends and share buybacks while reducing CapEx levels (Jones, 2021; Farhi \& Gourio, 2018; Blundell-Wignall \& Roulet, 2013).

- The risk-aversion was piqued for the investment committees of public corporations as central banks failed to achieve stated policy targets and then provided inconsistent messaging about future policy settings (IMF, 2015).

22 This is counterintuitive but related to the Modigliani-Miller theorem. A company's value is independent of its liability structure. Investors can readily reproduce any leverage structure through personal lending or borrowing to buy a given set of assets. So, even assuming the cost of debt financing falls under QE, shareholders still require company assets to generate a given rate of return. This only increases the required return on equity to achieve a given weighted average cost of capital. Hence, this is perhaps part of the reason we see an investment strike in countries employing QE policies. 


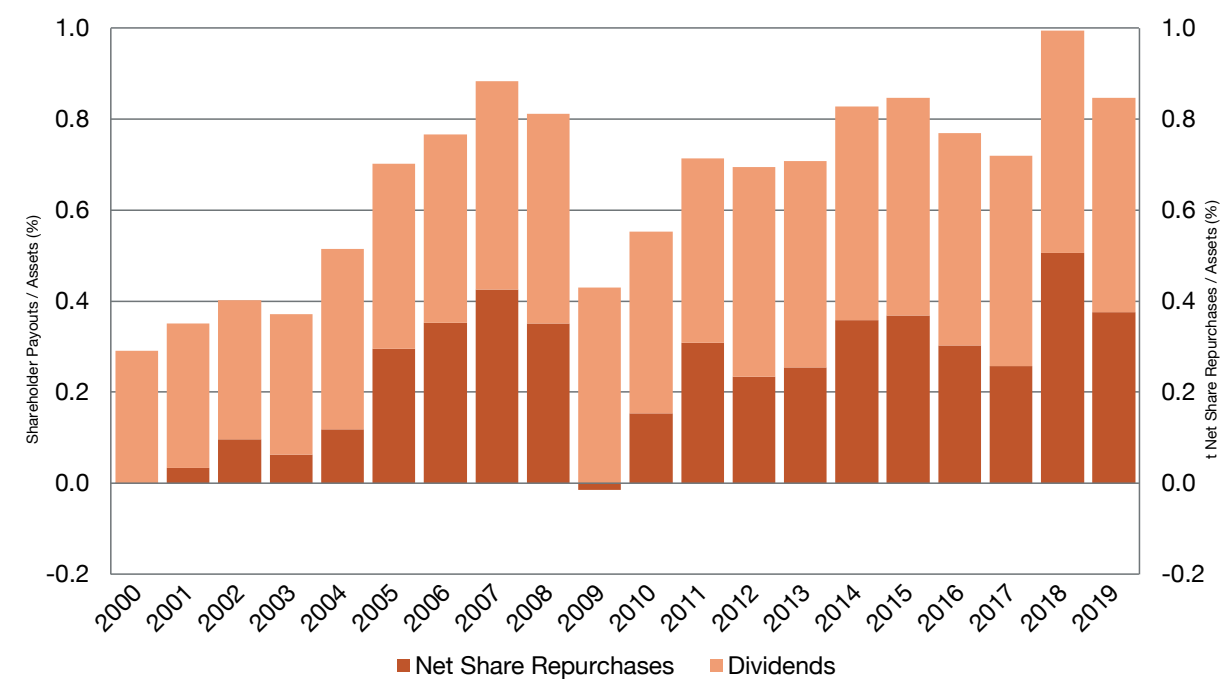

Figure 6. US repurchases and dividends (normalised by firm assets)

Source: Data from Compustat, 2001-19 (inclusive), as presented in Acharya \& Plantin (2019).

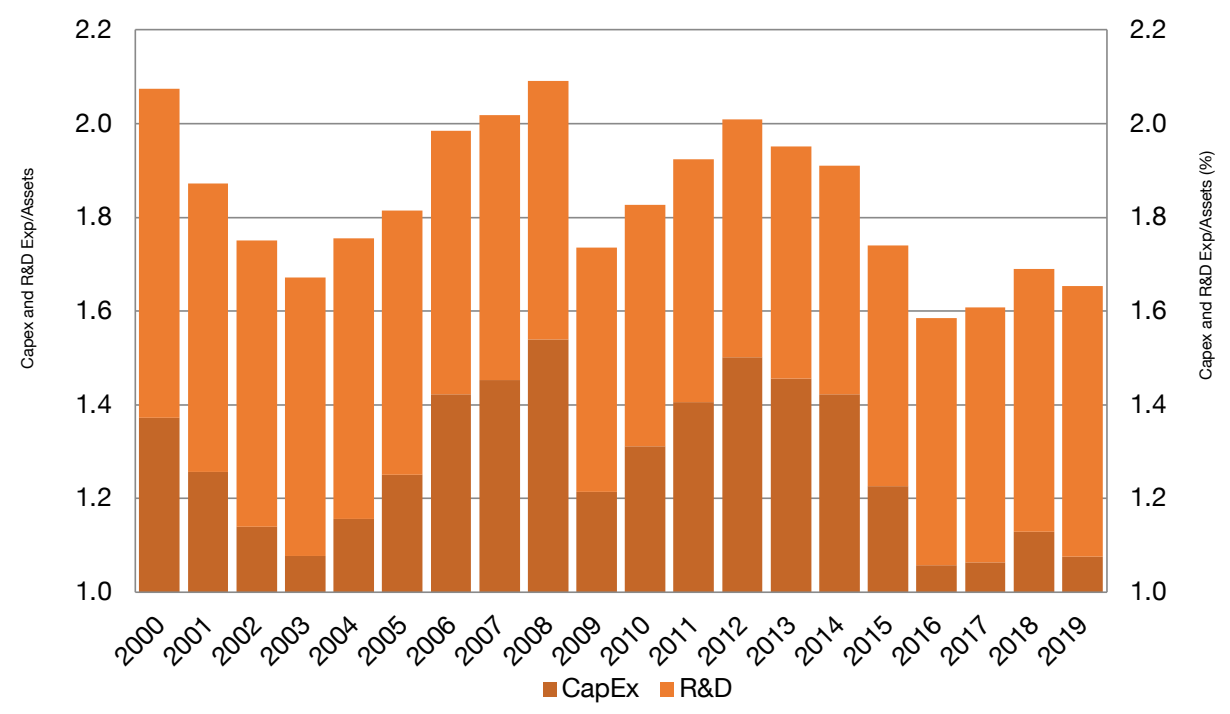

Figure 7. US CapEx and research and development (normalised by firm assets)

Source: Data from Compustat, 2001-19 (inclusive), as presented in Acharya \& Plantin (2019).

- In the absence of corporate confidence in future growth prospects, low rates facilitated large leveraged payouts by firms, which were detrimental to capital expenditure levels and led to suboptimal investment from a social perspective (Acharya \& Plantin, 2019) (Figure 6). 


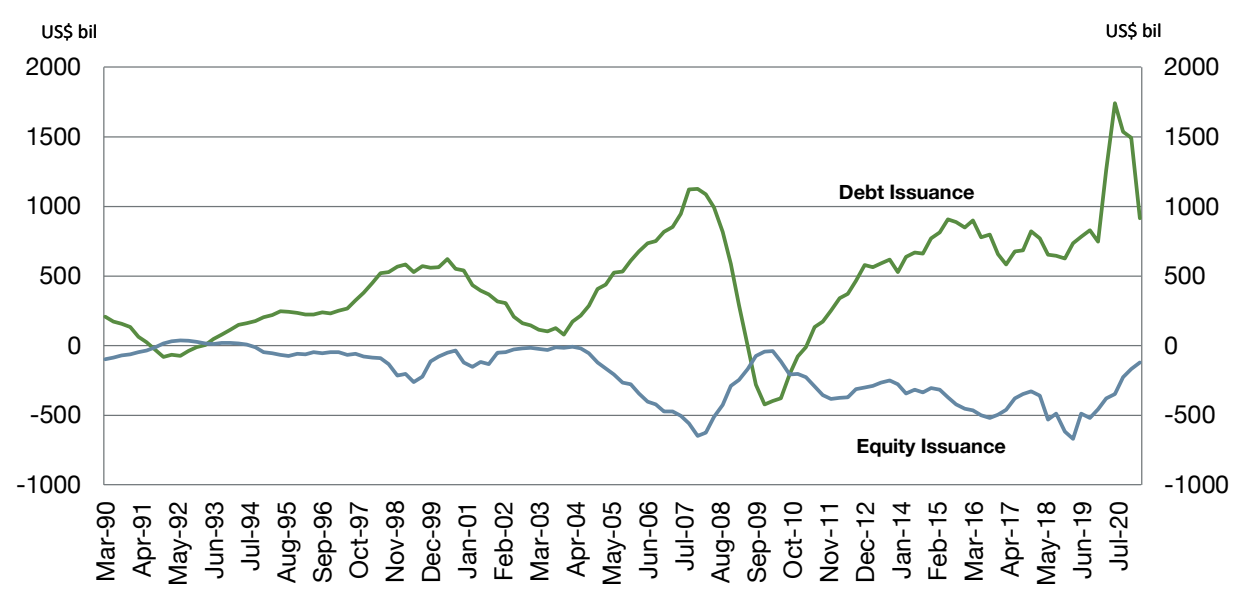

Figure 8. US private debt and equity issuance

Source: Montier (2018).

- If $\mathrm{QE}$ involves a preference for current income, it could potentially depress business investment by raising the market value of shareholder distributions relative to the expected return on long-lived capital (Spence \& Warsh, 2015; Thomas, 2016).

$\mathrm{QE}$ is certainly not the sole reason for the secular slowdown of business investment (think China's emergence, demographics, technology trends and so on), but we argue it is the major policy-based reason in the 2010s. It is worth noting that this finding runs counter to James Tobin's Q-theory, in which firms are induced to invest as the market value of investment assets rises relative to replacement value (Kaldor, 1966). Of course, Q-theory does not account for uncertainty. ${ }^{23}$

Of course, the by-product of QE policies' effectiveness in inflating asset prices has been the apparent insensitivity of consumer prices to monetary stimulus. Data on the so-called Phillips curve over the past 60 years for Australia illustrate clearly the impermanent relationship between output and prices. ${ }^{24}$ This is consistent with Solow (1998), who considers the whole Phillips curve apparatus, including neutral rate measurement, as soft as a grape - presumably, part of the dark arts of central banking. Looking at Figure 8, who could blame him?

23 Uncertainty reflects perceptions or beliefs, while risk-aversion reflects behaviours.

24 Another interpretation is that the relationship has fallen through time and is now imperceptible. 


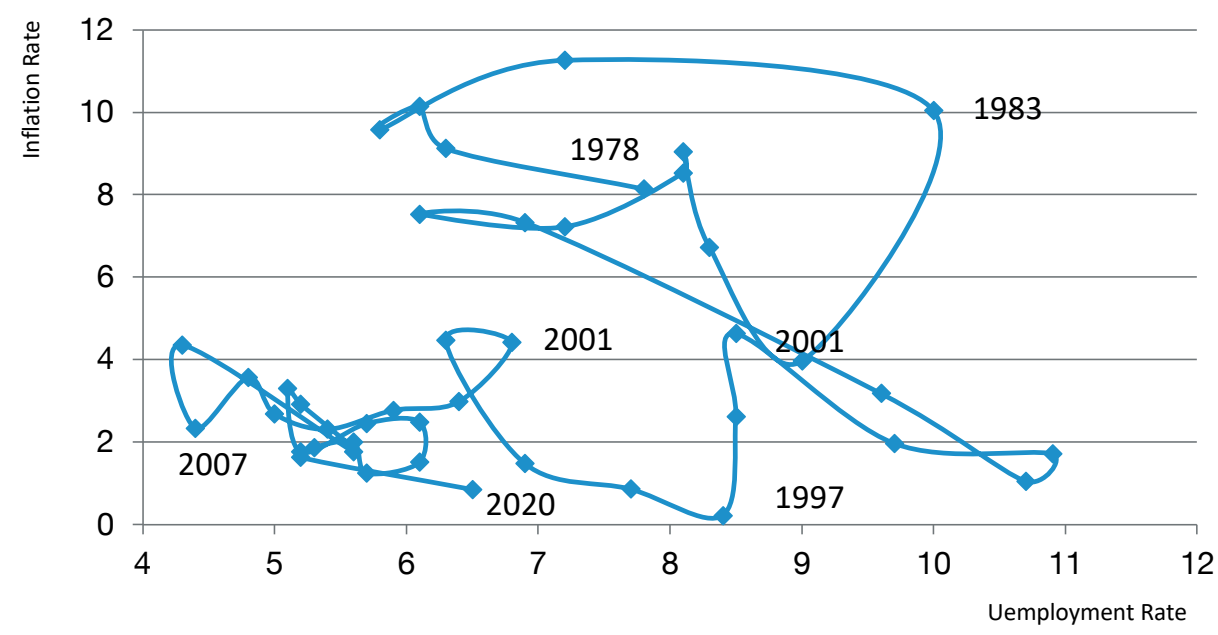

Figure 9. Phillips curve follies, 1

Sources: Melbourne Institute \& Australian Treasury using ABS data.

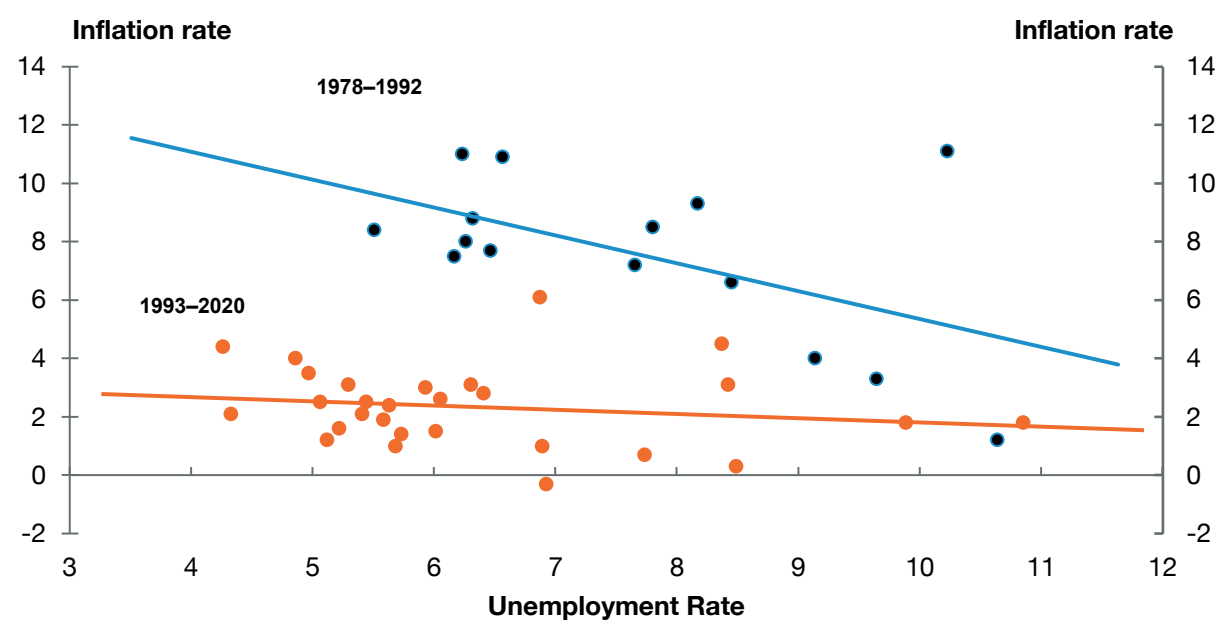

\section{Figure 10. Phillips curve follies, 2}

Note: Thanks to Professor Guay Lim from the Melbourne Institute and Luke Yearman from the Australian Treasury for their assistance in reproducing these charts.

Sources: Melbourne Institute \& Australian Treasury using ABS data.

Before closing this section, it is worth documenting another deleterious consequence of $\mathrm{QE}$ - that is, the enormous widening of inequality across advanced economies. This is because existing owners of assets benefit from price inflation and can use those same assets as collateral for new acquisitions. In a sense, this impact would be relatively neutral if each of us had the same propensity to consume out of each dollar of permanent income. But the problem is that the uber-wealthy have a very 
low propensity to consume. So, a significant widening in inequality is antithetical to running effective countercyclical policy and leads to a veritable uprising in social instability, which has been prevalent across economies. Evidence of this is the fact the combined wealth of the billionaires on Forbes magazine's annual global list rose a record US\$5 trillion to US\$13 trillion in the year ended April 2021 in the face of the greatest global pandemic since the end of World War I. The reason, of course, was QE (El-Erian, 2021).

\section{What QE is causing at the microlevel}

Apart from most likely driving some adverse macro-impacts that result in 'shallow recoveries' and boom-bust asset pricing, $\mathrm{QE}$ is likely driving longer-term portfolio efficiency impacts with big price tags.

\section{Risk of unstable debt burdens}

Certainly, the central government balance sheets (central banks and treasuries) of major economies around the globe, including Australia, are far larger now than they were in 2007 or before the Covid-19 crisis, with total assets at around US\$26 trillionUS\$22 trillion more than at the end of 2006, and far larger in GDP terms.

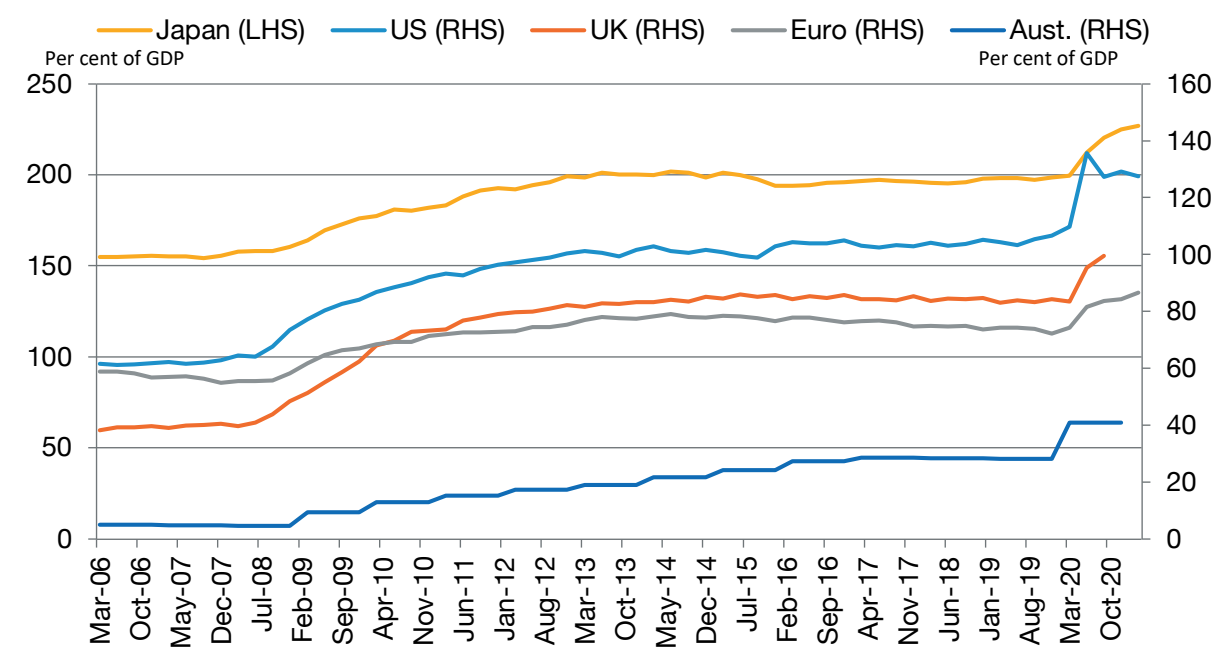

Figure 11. Central government net debt since 2006

Note: Australian data are federal government financial gross debt.

Sources: AOFM; ABS; Eurostat; BoJ; US Treasury; Haver. 
The Fed's balance sheet has already reached US $\$ 8$ trillion, or 35 per cent of GDP, and would be expected to rise rapidly, with the Congressional Budget Office estimating the US federal budget deficit will be around US $\$ 3$ trillion in fiscal year 2021.

The Bank of Japan's balance sheet exceeds 130 per cent of GDP, and sits at around 60 per cent of OECD member country output. Most of these governments are also now running big budget deficits.

Even the RBA is now rolling out a version of $\mathrm{QE}$, has committed to buying more than $\mathrm{A} \$ 5$ billion each week of federal and state government bonds and is closing on holding one-quarter of all outstanding issuance.

In terms of recent growth, the International Monetary Fund (IMF) has projected that, by year end 2021, the government debt loads in many developed market economies-including the United States, the United Kingdom, Italy, Japan and Australia — will have risen by 10 per cent of GDP since the pandemic began.

\section{Risk of market domination}

In addition to the sustainability of net debt issuance by central governments, swelling central bank balance sheets are now dominating the financial systems of certain market economies in a manner that cannot be easily unwound.

In theory, financial markets are supposed to be free of uncompetitive influences, with participants of roughly equal size. Large-scale QE has interfered here, as we saw above with the discussion of intermediation. Further, central banks in the United States and especially Japan and Europe have moved beyond being 'lenders of last resort' to become major players and determiners of market prices. This is because monetary transmission now involves capital asset markets as well as traditional money markets because of the institutional rise of repos, among other things. Moral hazard is now built into investor expectations of many asset prices.

For example:

- The Bank of Japan already holds $¥ 500$ trillion or around half of all Japanese Government Bonds and 10 per cent plus of all Nikkei-indexed exchange-traded funds (ETFs).

- The Fed owns US\$2.2 trillion, or some 33 per cent, of outstanding US mortgagebacked securities.

- The Fed and the European Central Bank have now started buying corporate debt and ETFs as well. 
In the past eight months, the RBA has gone from a standing start to owning between one-quarter and one-third of all Australian sovereign debt on issue. Unlike other market participants here, it is not buying bonds as part of a broader diversified portfolio, but for policy reasons-so the economics of its holdings are different. ${ }^{25}$ But just because it can, does not mean the RBA should.

Now each time financial markets wobble, central banks exercise the 'Greenspan put'. They cut interest rates if they can or undertake QE measures. This results in central banks holding bigger and bigger balance sheets.

As central banks have bought more and more varied asset types, including funding SME loans and even paycheque loans, they have implicitly become the largest underwriters of credit risk in their respective economies.

While only time will tell how much government debt the RBA is willing to buy, Governor Philip Lowe is on record as saying the RBA is 'prepared to transact in whatever quantities are necessary to achieve this objective' - that is, keeping funding costs low.

\section{Risk of central banks distorting portfolio returns}

If central banks are inadvertently guiding resources to lower-value activities, that distorts prices and risk. When capital flows towards bad bets and away from safer bets, we all pay for the consequences in terms of the risk-adjusted returns earned by investment portfolios through time. For portfolio managers looking to construct efficient mean-variance portfolios, the actions of central bankers introduce inefficiency by raising uncertainty around risk-free discount rates (zero-beta portfolios) and asset valuations. This efficiency cost is ultimately borne by savers (Figure 12).

The outcome must be reduced dynamic efficiency and productivity, greater instability and greater risk of financial contagion:

- The outcome for portfolios must be lower risk-adjusted returns over the medium term.

- The outcome for the typical householder will be less secure employment and a retirement more reliant on social security.

25 In comparison, no entity could gain such a large market share in the forex market, where daily turnover is around $\$ 7$ trillion as the fifth-most traded currency. 


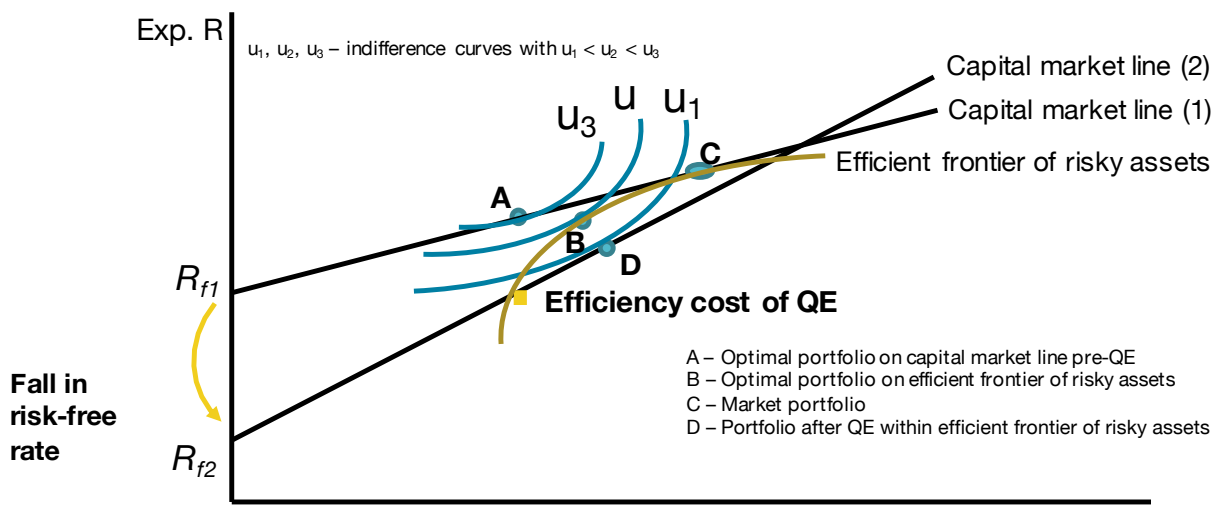

Figure 12. Distorting the risk-return trade-off for investors

Source: Author's work.

So, central bankers are inadvertently guiding resources to lower-value activities, distorting prices and risk. What might sound theoretical and far off is not so remote when you look at the latest dynamic allocation portfolio expectations of the big Boston-based value fund GMO (Figure 11). Its medium-term projection for returns over the next decade sees every asset class in the advanced economies in the red based on mean reverting dynamic asset allocations.

When capital flows towards bad bets and away from safer bets, we all suffer the consequences. It all sounds like Friedrich Hayek's worst nightmare. Here, monetary easing effectively subsidises business activities that are not socially desirable (but are privately profitable) at the expense of preferable investments (Hayek, 1931). All this sounds very bad for dynamic efficiency and capital formation through time.

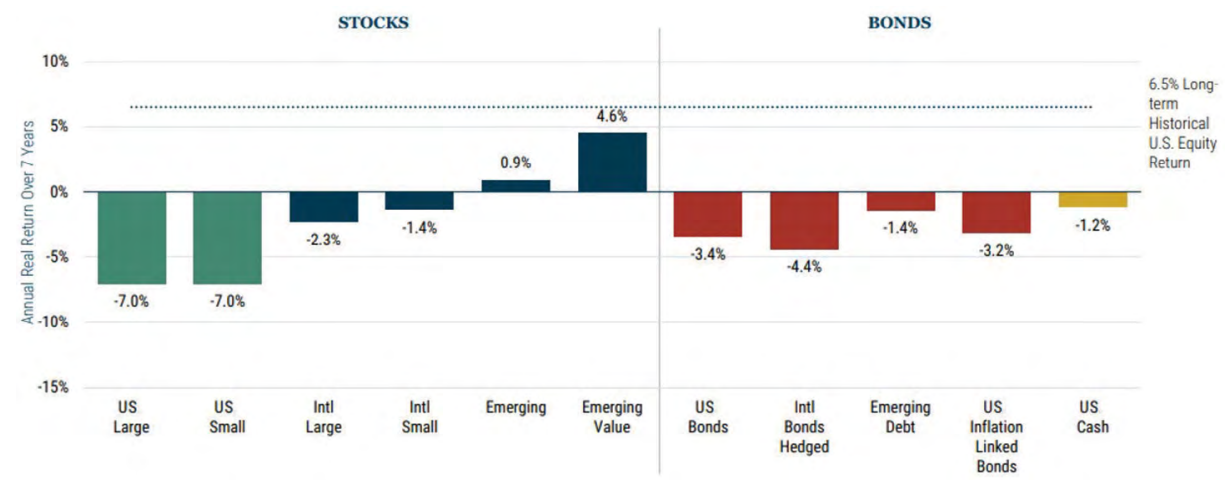

Figure 13. Seven-year asset-class real return forecasts

Source: GMO (2021). 


\section{Risk that central banks have lost reversibility}

Another fundamental risk with QE policies is reversibility. When the Fed tried to reverse out of QE from 2017 onwards (via cautious limited selling of its asset holdings), this culminated in a liquidity crunch in the repo markets in late 2018, which provided the backdrop to the current Covid-19 monetary easing. During the Covid-19 crisis, central banks went even further than before by making absolute commitments to 'QE infinity', which in our view is a certain signal that unwinding will not occur and policy will impact the value of resources. Unstable money does not promote macroeconomic stability. Policymakers caught in this QE vice will find that bigger private debt requires larger and more frequent debt rollovers, which will see central banks running QE to support liquidity flows. Each time financial markets wobble, larger and larger liquidity injections are required to thaw frozen markets and resuscitate economies, as effective intermediation becomes harder and harder to accomplish.

It does seem that $\mathrm{QE}$ has become a one-way bet. The more participants expect quantity injections and aggressive posturing by central banks at the first sign of market trouble, the harder it is to roll back the cumulative load of previous episodes.

\section{Policy messages}

Once upon a time, central banks' settled role was monetary oversight centred on the regulation and pricing of the money supply. These critical levers were its cardinal tools. Origination, while important, was utilised generally only to assist and enhance the objectives pursued via its primary tools.

\section{Overreach}

But today the gamekeeper has turner poacher; the long-lost, conservative inventory manager has now assumed centre-stage as a financial market player whose reach and power far exceed the most aggressive of banks within its supervisory control.

The obvious result is the utter corruption of our financial markets' key role and responsibility: the intermediation of credit and the making of investments based on the application of the fundamental principle of the risk-reward equation.

The insidious result is the concentration of liquidity among the major financial market players, who regularly pledge allegiance to their central bank (and regulatory agency) overlords in consideration for protection from competition. 
Central banks have stumbled into unhealthy co-dependency with markets, risking policy flexibility and the longer-term credibility that is critical to their effectiveness. Assets under management and margin debt are at record levels, as is the indebtedness of central bank balance sheets (El-Erian, 2021).

Central banks are effectively selling call options enabling protected exposure to the upside of financial assets - for a price, which is that market participants must secure liquidity and keep investing. The objective of QE seems to have more to do with the security of financial markets than with the wellbeing of households. With central bankers deciding a new role for themselves of backstopping asset prices, they are engaging in mission creep. Sadly, they are even now grading their own performance (Fabo et al., 2020).

So, while we understand how central banks got into this position, we have argued it is not a good place to be and it would certainly take some chutzpah to stay there. ${ }^{26}$

\section{Finetuning}

Perhaps the critical error central bankers have made is their belief that they can turn the supply of financial flows 'on and off. Confidence in our ability to finetune stems from our standard macroeconomic models in which money is mainly exogenous and neutral in terms of its impact on output over time. That may have been an accurate depiction of the world before the 1980s and the emergence of huge pools of institutional capital driven by the savings of baby boomers. But bank funding models and balance sheets have changed markedly since most mainstream macroeconomic theory was written in the 1970s and 1980s.

The fundamental role of central banks is to ensure monetisation of 'liquidity'. This they do via funding and interventions in capital markets to bolster collateral. Liquidity is always endogenous. Money has a major discretionary dimension to it.

In our view, the best thing central banks can do now is maintain liquidity in markets while gently and gradually reversing away from their quantitative balance sheet expansions. It seems that a large part of the problem of the past decade has been keeping rates too low. At the same time, authorities have not dealt well with money market imbalances. So, creating some sort of 'permanent repo' facility to smooth money market shortfalls would be a positive step. They should enhance countercyclical lending standards in residential property and other credit categories that are fuelling boomtime conditions.

\footnotetext{
26 Central bankers are not all-seeing and all-knowing. For example, the RBA has persistently undershot its inflation target in a manner as systematic as Treasury's budget surplus forecasting performance in the 2010s. The RBA enjoys an elevated position in the policy hierarchy, which allows it to comment with seeming impunity on every aspect of economic policy, including climate change. It is surrounded by an echo chamber of bank economists who never call it out, with one or two exceptions. While we do not question the RBA's public spiritedness, it must sometimes surely act in its own interests, so we question its capacity to withdraw from the QE honeypot.
} 
In the longer term, we may need a more 'elastic' monetary and banking system (Kaldor, 1972). This approach only allows the money to grow in automatic response to an increase in demand for credit where that demand arises from business use and especially the requirements of SMEs and first homebuyers. Surely monetary and tax facilitation of speculation are not a good thing.

\section{Operational separation}

One of the most important considerations for monetary and fiscal monetary policy operations under QE is the dubious case for operational independence of monetary policy from fiscal policy. While central banks have a monopoly on interest rate policies, almost any balance sheet policy is replicable by the broader government (Borio \& Disyatat, 2009). Where monetary authorities are effectively backstopping domestic fiscal expansions, both policies are bound together. There is one government, and it has one budget constraint, so monetary and fiscal policy are not independent (Prescott, 1999). Indeed, there are very complex interactions between money supply, government expenditure and debt management in this world of endogenous 'quantity' money. Bringing the whole lot together in one institution makes perfect sense, especially if it is all accountable to a minister and voters.

\section{Guideposts}

Another part of the problem of 'money' in economics relates to the Keynesian and monetarist divide_-both of which are right and wrong at the same time. Monetarists are right to want to restrict the flow of liquidity to some predictable average growth rate. The problem is they cannot find a way to operationalise the rule given the substitutability of credit forms. Meanwhile, Keynesians tend to a more practical understanding of money and endogeneity, but often eschew the use of target rules that might stem fiscal slippage through time.

In present circumstances, the obvious answer to the broader policy predicament is to target a given unemployment rate (say, 5 per cent) and rely mainly on fiscal policy with accommodative monetary policy in support. We say this is the fastest path back to economic normality.

\section{Defining money}

Money is, in our view, any equivalent asset that provides a warehouse of value. It is also a benchmark of the soundness of a government's institutional macro-policies, which must be time consistent-in other words, anchored by a neutrality objective 
or a pledge that, over time, governing authorities will not enact policies that impact the risk-return equation through time. As you can see, we have been thinking about this answer for 20 years so far. Thank you for your service, Ted Evans, rest in peace.

\section{References}

Acharya, V. \& Plantin, G. (2019). Monetary easing, leveraged payouts and lack of investment (Working Paper, July). NYU Stern School of Business. doi.org/10.3386/w26471.

Black., F. (1987). Business cycles and equilibrium. Blackwell.

Blundell-Wignall, A. \& Roulet, C. (2013). Long-term investment, the cost of capital and the dividend and buyback puzzle. OECD Journal: Financial Market Trends, 1, 39-52. doi.org/10.1787/fmt-2013-5k41z8t05l8s.

Borio, C. \& Disyatat, P. (2009). Unconventional monetary policies: An appraisal (BIS Working Papers 292, November). Bank for International Settlements. doi.org/10.2139/ ssrn. 1541243.

Borio, C., Disyatat, P., Juselius M. \& Rungcharoenkitkul, P. (2017). Why so low for so long? A long-term view of real interest rates (BIS Working Papers 685, December). Bank for International Settlements.

Brunner, K. (1983). Conversation with a monetarist. In A. Klamer (ed.), Conversations with economists: New classical economists and opponents speak out on the controversy in economics. Rowman \& Littlefield.

Deutsche Bank Research. (2019). The history and future of debt: Long-term asset return study, 23 September. Deutsche Bank.

El-Erian, M. (2021). Echoes of the GFC as finance threat returns. Australian Financial Review, 11 June, 2R.

Fabo, B., Jančoková, M., Kempf, E. \& Pastor, L. (2020). Fifty shades of QE: Conflicts of interest in economic research (Working Paper 2020-128, October). Becker Friedman Institute for Research in Economics.

Farhi, E. \& Gourio, F. (2018). Accounting for macro-finance trends: Market power, intangibles, and risk premia. Brookings Papers on Economic Activity, Fall, 147-250. doi.org/10.1353/ eca.2018.0024.

Friedman, M. (1956). The quantity theory of money: A restatement. In M. Friedman (ed.), Studies in the quantity theory of money. University of Chicago Press.

Garnaut, R. (2021). Reset: Restoring Australia after the pandemic recession. La Trobe University Press.

GMO. (2021). Long term asset returns-As at 31 May. GMO. 
Hassett, K. (2020). International keynote address to the 2020 AFR Business Summit. Sydney, 10 March.

Hawtrey, R.G. (1925). Public expenditure and the demand for labour. Economica, 5(13), 38-48. doi.org/10.2307/2548008.

Hayek, F.A. (1931). Prices and production. Augustus M. Kelley Publishers.

Holston, K., Laubach, T. \& Williams, J.C. (2017). Measuring the natural rate of interest: International trends and determinants. Journal of International Economics, 108(S1), May, 39-75. doi.org/10.1016/j.jinteco.2017.01.004.

Howell, M.H. (2020). Capital wars: The rise of global liquidity. Palgrave Macmillan. doi.org/ 10.1007/978-3-030-39288-8.

International Monetary Fund (IMF). (2015). Private investment: What's the holdup? Chapter 4: Uneven growth-Short- and long-term factors. World Economic Outlook, April. International Monetary Fund.

Jones, B. (2021). Uncertainty and risk aversion: Before and after the pandemic. Keynote address at the Minerals Week Australia-Asia Investment Outlook. Reserve Bank of Australia, Canberra, 2 June.

Kaldor, N. (1966). Marginal productivity and the macro-economic theories of distribution: Comment on Samuelson and Modigliani. The Review of Economic Studies, 33(4), 309-19. doi.org/10.2307/2974428.

Kaldor, N. (1972). The irrelevance of equilibrium economics. Economic Journal, 82(328), 1237-55. doi.org/10.2307/2231304.

Keynes, J.M. (1936). The general theory of employment, interest and money. Macmillan.

Keynes, J.M. (1937). Alternative theories of the rate of interest. Economic Journal, 47(186), 241-52. doi.org/10.2307/2225525.

Krugman, P. (2021). The week the inflation panic died. The New York Times, 21 June.

Lucas, R.E., Jr. (2014). Liquidity: Meaning, measurement, management, review. Federal Reserve Bank of St Louis Review, 96(3), 199-212. doi.org/10.20955/r.96.199-212.

Modigliani, F. (1944). Liquidity preference and the theory of interest and money. Econometrica, 12(1), 45-88.

Modigliani, F. \& Miller, M. (1958). The cost of capital, corporation finance and the theory of investment. American Economic Review, 48(3), 261-97.

Montier, J. (2018). The late cycle lament: The dual economy, Minsky moments, and other concerns (GMO White Paper, December). GMO.

Morgan, B. (1978). Monetarists and Keynesians: Their contribution to monetary theory. Macmillan. doi.org/10.1007/978-1-349-15963-5. 
Prescott, E. (1999). Edward C. Precott. In B. Snowden \& H.R. Vane (eds), Conversations with leading economists: Interpreting modern macroeconomics. Edward Elgar.

Ryan-Collins, J. (2015). Is monetary financing inflationary? A case study of the Canadian economy (Working Paper No. 848, October). Levi Economics Institute. doi.org/10.2139/ ssrn.2679090.

Samuelson, P. \& Barnett, W.A. (2007). Inside the economist's mind: Conversations with eminent economists. Blackwell.

Sheedy, K.D. (2020). Taking away the punch bowl: Monetary policy and financial instability (Research Paper, September). London School of Economics.

Solow, R.M. (1998). How cautious can the Fed be? In R.M Solow \& J.B Taylor, Inflation, unemployment, and monetary policy. MIT Press.

Spence, M. \& Warsh, K. (2015). The Fed has hurt investment: QE is partly to blame for record share buybacks and meagre capital spending. The Wall Street Journal, 26 October.

Summers, L.H. (2013). Why stagnation might prove to be the new normal. Financial Times, 15 December.

Thomas, J.M. (2016). John Bull can't stand 2 percent: QE's depressing implications for investment. 25 March. doi.org/10.2139/ssrn.2754665.

Tinkler, M. (2020). Painful truth of the great monetary experiment. Australian Financial Review, 2 November.

Trott, D. (2015). Australia and the zero lower bound on interest rates: Some monetary policy options. Agenda: A Journal of Policy Analysis and Review, 22(1), 5-20. doi.org/10.22459/ AG.22.01.2015.01. 
This text is taken from Agenda, Volume 28 - Number 1, 2021 edited by William Coleman, published 2021 by ANU Press, The Australian National University, Canberra, Australia.

doi.org/10.22459/AG.28.01.2021.03 